\title{
PSICHOLOGINĖS PRIEMONĖS, PALAIKANČIOS ŽMOGAUS EGZISTENCIJĄ KALĖJIME
}

\author{
Arvydas Ramonas, Irena Jonikaitè \\ Klaipèdos universitetas
}

\begin{abstract}
Anotacija
Straipsnyje analizuojamos psichologinès žmogaus egzistencija kalëjime palaikančios priemonès. Pagrindiniu šaltiniu pasirinktas rusu literatūros klasiko Fiodoro Dostojevskio (1821-1881) romanas ,,Užrašai iš mirusiuju namu“ (1861-1862), parašytas remiantis jo asmenine politinio kalinio patirtimi (1849-1859). Autorius virš niūraus gyvenimo kalejime, skurdžios buities ir nuteistujų nužmoginimo iškelia pastangas išlikti žmogumi ir kalèjimo sistemos užslopintus asmens gerumo pradmenis. Straipsnyje svarstoma, kodèl kaliniai büdami toje pačioje aplinkoje jaučiasi skirtingai. Nuteistuju psichologinè poreikiu tenkinimo elgsena atitiko amerikiečiu psichologo Abraham'o Maslow'o sudarytą žmogaus poreikiu hierarchiją ir pasikeitusia laisvès sampratą. Išgyventi padejo kitoks kalejjime praleisto laiko suvokimas, kaip neegzistuojantis žmogaus gyvenime, ir fizinis darbas, kaip būdas užsimiršti. PAGRINDINIAI ŽODŽIAI: Fiodoras Dostojevskis, Užrašai iš mirusiujų namu, psichologija, egzistencija.
\end{abstract}

\begin{abstract}
The article analyzes the psychological measures that support human existence in prison. The main source chosen is the novel "Notes from the House of the Dead" (1861-1862) by Fyodor Dostoevsky (1821-1881), a classic of Russian literature, which was written based on his personal experience as a political prisoner (18491859). The author, above the gloomy life in prison, the poor household and the dehumanization of convicts, raises the effort to remain human and the hidden features of personal goodness hidden in the prison system. The article discusses why prisoners feel differently being in the same environment. The provision of needs according to the hierarchy of human needs established by the American psychologist Abraham Maslow and the changed concept of freedom served as a psychological support for the convicts. Survival was aided by a different perception of time spent in prison as non-existent in human life and physical work as a way to be forgotten.

KEY WORDS: Fyodor Dostoevsky, Notes from the House of the Dead, psychology, existence.
\end{abstract}

DOI: http://dx.doi.org/10.15181/mtd.v0i7.2309 


\section{Ivadas}

Rusų literatūros klasiko Fiodoro Dostojevskio (1821-1881) romane „Užrašai iš mirusiujjų namų“ vaizduojamas paties autoriaus patirtas kalinio gyvenimas. Ši bausmė jam skirta už dalyvavimą draustoje revoliucinejje veikloje, kuriai vadovavo visuomenès veikejas Michailas Petraševskis (1821-1866). Vadinamujjų petraševskininkų draugijoje rinkdavosi inteligentai, kèlę valstybès reformų ir baudžiavos panaikinimo idejjas. Bendrijos veikla nutraukta 1849 m. jos nariams skyrus bausmę - išsiuntimą ị katorgą.

Romanas pirmą kartą išspausdintas $1861 \mathrm{~m}$. brolių Michailo ir Fiodoro Dostojevskių leistame mėnesiniame žurnale „Vremia“ (užbaigtas publikuoti 1862 m.). „Cenzūra ne iš karto sutiko leisti „Užrašus“, netiketai motyvuodama tuo, kad katorga pavaizduota per daug šviesiomis spalvomis - žmonès nebebijosią bausmès“ (Červinskienè, 2004, p. 101). Nes kalinių gyvenimą aprašè ne tik kaip griežtą taisyklių laikymąsi, bet ir pastebėtą jų žmoniškumą. Cenzūra griežtai vertino viską, kas buvo rašoma apie kalejjimus. Kad nebūtų tiesioginių romano turinio ir autoriaus sąsajų, F. Dostojevskis sugalvojo personažą Aleksandrą Petrovičių Goriančikovą, kuris nužudė savo žmoną. Literatūros forma jis sieke perteikti ten vykusi gyvenimą. „Tai, kas išgyventa, o taip pat nelaimès draugų paveikslai, jų pasakojimai apie save, buitis, katorgos papročiai - visa tai turejo tapti dokumentu kitos, meninès tiesos apie mirusiųų namus ir jų gyventojus - žuvusią tautą“ (Inis, 1999, p. 107). Išleistas romanas sulaukè didžiulio pasisekimo ir autoriaus pripažinimo. Literatūros salonuose dažnai prašydavo F. Dostojevskio paskaityti ištraukas iš šio romano. Anot jo dukros Liubovès Dostojevskajos, pasirodžius „Užrašams iš mirusiųjų namų“F. Dostojevskis tapo vienu žymiausių rašytojų ir šios pozicijos nebeprarado.

Literatūros kritikas Michailas Bachtinas veikejjų gyvenimą „Užrašuose iš mirusiųų namų“ pavadina „gyvenimu, išimtu iš gyvenimo“. Tai krizès laikas, kai pasineriama ị save. „Visa tai - laikas ant slenksčio, o ne biografinis laikas, gyvenamas tolesnèse nuo slenksčio vidinėse gyvenimo erdvėse“ (Bachtin, 1996, p. 206). Autorius, cituodamas F. Dostojevskio laišką, pamini, kad iki šio rašytojo gyvenimo kalèjime dar niekas nėra aprašęs. Knygos pavadinimas perteikia visą kūrinio esmę - brangiausias žmogaus turtas - turèti savo valią, o kalëjime nei valios, nei laisvès nuteistasis neturi. Jis tarsi miręs 
vidumi. „Kaliniai pratrūksta dèl neišvengiamo troškimo turèti savo valią, tas potraukis svarbesnis už jų pačių gerovę, tiesą sakant, ir už pati gyvenimą“, teigia literatūros kritikas Gari’s Morson'as (Morson, 2021, p. 5). Profesorius, gilinęsis ị šio rašytojo kūrinius laisvès aspektu, atskleidè, kad po kalëjime praleistų metų F. Dostojevskio kūryboje išnyksta naivus, viltingas romantizmas ir sustiprèja religijos gelmè. Kalinių ir sargybinių sadizmas jam ịrodè, kad pozityvioji žmogaus prigimtis, propaguota socializmo, yra absurdas. Jis tik šiek tiek tepakeite gyvenimo kalejjime ịvykius, siekdamas pavaizduoti juos romane. Rašytojo dèmesys kreipiamas ị žmogaus santykị su jị supančia aplinka. Jis domėjosi žmogaus visuma: elgesio motyvais, psichikos procesais, moraliniais instinktais, sielos gelme. Realūs faktai, pateikti menine forma, jam atrodè turintys didesnę gelmę ir paveikesni nei prasimanytos istorijos.

Romane aprašomas kalëjimas - vienas iš tų, kuriame kaliniai laikyti „dulkès“ vietoje, i juos žiūreta ne kaip ị asmenis, pasižyminčius unikaliomis charakterio savybėmis, bet kaip į niekingų žmonių masę. Žmogus nužmogintas sociologiniu ir dvasiniu požiūriais. Tarp agresyviụjų romano veikẻjų pastebimi ir ramesni kaliniai, tik jie užgožiami bendro kalëjimo žiaurumo. Rusų literatūrą tyrinejjusio profesoriaus Lewis'o Bagby'io teigimu, tai ne tik kalejjimo, bet visos žmonijos tragedija. „Dostojevskiui dvasinio pasaulio prasiskverbimas ị žemiškają egzistenciją reiškia grižimą ị teigiamą žmogaus šerdị, kuri yra jo pagrindas, neatmetant ir ydingumo“ (Bagby, 2016, p. 55). Tai gręžimasis ị moralę, kai ieškoma atsakymų ị klausimus, kas yra gera, o kas - ne. Slogioje aplinkoje pastebimas net menkiausias bandymas išgyventi tamsą. Literatūrologas pridūrè, kad romano autorius kalinị vaizduoja atskleisdamas abi puses - nežmonišką išsigimimą ir humanišką potencialą.

F. Dostojevskio valia kai kurie personažai, nepaisant juos supančios aplinkos, išliko psichologiškai atsparūs. Jiems padejo galimybė tenkinti pamatinius žmogaus poreikius, laisvės simbolizmas ir darbas, kaip užsimiršimo priemonè. Daugeliui veikèjų vardai nesuteikti, jų charakterių bruožai apibūdinti taip, kad tiktų kiekvienam kaliniui. Pavyzdžiui, troškimas patenkinti savo poreikius buvo būdingas visiems kaliniams, o ne kuriam konkrečiam, tuo tarpu nepasiduoti nužmoginimui labiau stengèsi ramesnieji. Autorius pagrindinio personažo mintimis byloja: kaip laisveje yra gerų ir blogų žmonių, taip ir kalejjime. Pastarajame ieškoma žmoniškumo - blogyje gėrio. 
Darbo tikslas: išanalizuoti psichologines priemones, palaikančias nuteistujų egzistenciją ribojimo veiksniams kalëjimo sąlygomis veikiant.

Darbo objektas - F. Dostojevskio autobiografinis romanas „Užrašai iš mirusiųjų namų“ (1861-1862).

Darbo metodai: istorinis aprašomasis, mokslinès literatūros ir Bažnyčios dokumentų analizè, interpretacija, sintezè.

\section{Kodėl vieni kalẻjime jaučiasi gerai, o kiti - ne?}

„Užrašuose iš mirusiujų namų“ išryškèja dvi žmonių grupès: vieni kalejjime jaučiasi gerai, tarsi nebūtų nuteisti ir kenčiantys asmenys, tuo tarpu kiti - prastai, lyg būtų sužlugdyti. Šie kontrastai nulemti keleto aplinkybių, kurios įvardytos pagrindinio herojaus samprotavimuose. Pirmiausia tai - sąžinè. Kažkam ji priekaištaus dèl padaryto neteisingumo ir tai kankins žmogų iš vidaus labiau nei pati kalèjimo bausmè: „Jis pats save nuteis už savo nusikaltimą negailestingiau, griežčiau už patị rūsčiausiaji ịstatymą" (Dostojevskis, 2006, p. 68). Dèl klaidos kenčiantị žmogu sąžinè vers atgailauti ir parodys atleidimo viltị. Kitu sąžinè bus nebyli, nuteistasis ,net ir nepagalvos nẻ sykio apie savo žmogžudystę per visą katorgos laiką. Jis net mano, kad yra teisus“" (Dostojevskis, 2006, p. 68). Sąžinè apibrèžia elgesio moralinę vertę, jos vedamas žmogus priima teisingus sprendimus, o ị ją neįsiklausant tolstama nuo žmoniškumo. „Žmogus turi savo širdyje Dievo įrašytą įstatymą, kuriam paklusti reikalauja pats asmens orumas; pagal tą ịstatymą jis ir bus teisiamas“ (Visuotinis Vatikano II Susirinkimas, Gaudium et spes, 1965, Nr. 16). F. Dostojevskis kelia mintị, kad kaliniai nevienodai jaučia ir supranta bausmès prasmę dèl sąžinès dèmens. Duotoji sąžinè leidžia skirti gèrị ir blogị. Kalinių atveju ji ,suveike“ tik padarius nusikaltimą, tad neapsaugojo, nelèmè teisingo sprendimo (nekenkti kitam) pasirinkimo. Kažkam ji parode padarytos žalos skausmą ir paskatino gailètis. Šis susitikimo su sąžine procesas kalejime tampa nepakeliamu psichologiniu sunkumu. Kitiems nuteistiesiems sąžinè nèra teisingo santykio su kitu žmogumi (galima pridurti ir su savimi bei Dievu) atkūrimo dalis. Vadinasi, asmens moralè yra žemo lygmens, kalëjimo bausmè tokio žmogaus nẻ kiek nepaveikia, nusikaltimo prasmė jam nesuvokiama: neteikia dvasinės kančios, neskatina nebenusikalsti. 
Kita priežastis - gyvenimo sąlygų skirtumai. Iki suėmimo materialiai geriau gyvenęs žmogus patekęs ị kalèjimą patiria šoką ir negeba adaptuotis. Tuo tarpu laisvejje vargęs žmogus atsidūręs kalejjime jaučia palaimą: „Ten jis gyveno paskutiniškai žeminamas, niekad nepavalgė sočiai ir dirbo savo darbdavio labui nuo tamsos lig tamsos“"(Dostojevskis, 2006, p. 68). Kalèjime jam ir maistas atrodo skanesnis, ir darbas lengvesnis, ir žmonès malonesni „smagus šaunuolių draugų klubas“. Laisvė jam buvo „katorgiškesne““ nei pats kalejjimas, o pastarajame nebereikia rūpintis fiziniu išlikimu (maistu, pastoge), gyventi patogiau nei skurdžiuose savo namuose. Lengvesnio gyvenimo troškimas tampa pretekstu nusikalsti, kai esama aplinka nebepakenčiama fiziškai ir psichologiškai, taigi nebepaisoma etiško elgesio normų. Atimtoji laisvè netampa bausme, o ịvykdytas nusikaltimas tik palengvina gyvenimą, neprisiimant atsakomybès už save.

Psichinę būseną veikè ir pati socialinè kalinių grupè. Vieni nuteistieji joje jautėsi savi, tuo tarpu kiti nepritapo. Vienas pastarujų - pagrindinis romano veikèjas Aleksandras Petrovičius Goriančikovas, kurio pirmosios (jos išliko beveik visą kalinimo laiką bendraujant su dauguma) emocijos buvo svetimumo jausmas ir liūdesys: „Baisus, gaižus maudulys vis labiau ir labiau èdè mane. „Mirusiųjų namai!“ - kalbejjau sau, žiūrẻdamas kai kada sutemose nuo savo kazarmès prieangio ị kalinius“" (Dostojevskis, 2006, p. 110). Stebẻdamas žmones veikèjas juose ịžvelgia sielos mirtị, netikrumą (išskyrus vieną kitą personažą), sužalotus ir dvasiškai palaužtus gyvenimus. Jų gyvenimas - tik pilka egzistencija. Goriančikovo įžvelgtas kontrastas tarp savos dar nesužlugdytos dvasinès būsenos ir nuteistujų vidinės tuštumos yra adaptacijos procesą kontroliuojantis veiksnys. Be abejo, nematant ị save panašiu „dar gyvų“ kalinių prisitaikyti nelengva. Ne tik neigiama psichologinè kalinių grupès būsena, bet ir herojaus ,atsineštoji“ padètis buvo jam nepalanki psichologiškai. „Goriančikovo nepritapimo patirtys kilusios ne dèl jo, kaip nuteistojo, padèties, bet yra vidinis - prigimtinis valstiečių ar nuteistujų bendruomenès - ne kitų visuomenès grupių - rezultatas“(Young, 2013, p. 1705). Bajoriškoji Goriančikovo kilmè ir naujoko statusas buvo priešiškumo jam pretekstas, nesusibendravimo su valstiečiais barjeras. 
Ketvirtoji prisitaikymo prie kalèjimo sąlygų skirtingumą lèmusi aplinkybė yra tikèjimas. Ko kalëjimo prižiūrètojai negalèjo atimti ir kaip nors valdyti, buvo nuteistujų maldingumas ir galimybè skaityti Šventajj Raštą. Religingieji jautèsi stipresni dvasiškai, nepraradę paskutinès vilties, kad ištvers skirtą laiką nelaisveje, jų asmenybių portretai šviesesni, optimistiškesni. Nereligingieji - niūresni, uždaresni, priekabesni, linkę pažeisti kalëjimo tvarką, nematantys gyvenimo prasmés. Dèl savo neprognozuojamo elgesio jie kelia nerimą ir nesaugumą kitiems kaliniams: nuolatinès muštynès, vagystės. Pavyzdžiui, vaikžudys Gazinas mane esąs pats svarbiausias, galintis elgtis kaip panorėjęs. Amerikiečių profesorius, kriminologas Todd'as Clear'as, analizavęs kalinių psichologinę būseną religingumo aspektu, pastebėjo, kad liūdnos gyvenimo pasekmès, tokios kaip ịkalinimas, dažnai nulemtos negebejjimo gyventi pagal religijos mokymą. ,Religija iš esmès nurodo galimus problemos sprendimus, nes ne tik paaiškina nesėkmès priežastį, bet ir rodo išeiț̨“ (Clear ir kt., 2000, p. 58). Būtent religija leidžia kaliniui suvokti jo nemoralaus elgesio pasekmes, joje jis atranda viltị atsitiesti ir taisytis, žinoma, čia būtina gailesčio sąlyga. Profesorius skiria tris religijos nulemtas savybes, kurios leidžia nuteistiesiems geriau jaustis: religija palengvina kovą su kalte; ieškoma naujos gyvenimo prasmės; lengviau priimama laisvès netektis.

\section{2. Žmogaus poreikių (remiantis A. Maslow'o poreikių hierarchijos piramide), tenkinimas kalẻjimo sąlygomis}

Žmogus iš prigimties turi poreikių, kurie, nepaisant aplinkybių - esama laisvèje ar kalèjime, turi būti tenkinami. A. Maslow'o teigimu, ,pagrindinis bet kokio poreikio patenkinimo padarinys yra tai, kad jis išstumiamas iš sąmonès (submerged) ir iškyla naujas ir aukštesnis poreikis“ (Maslow, 2009, p. 93). Tai reiškia, kad patenkinus žemesni poreikių piramidès poreikị, asmuo trokšta patenkinti aukštesni (pvz., patenkinus fiziologinius poreikius, siekiama saugumo, patenkinus saugumo, siekiama meilès ir t. t.). Nepatenkinus kurio nors poreikio, visas dèmesys sutelkiamas būtent $i \mathfrak{j}$ ji, kol jis bus patenkintas. Tuo metu kiti poreikiai slopinami. Poreikių tenkinimas veikia charakterio formavimosi procesą, nes poreikiai skatina žmogų veikti, sveikai 
vystytis ir tobuletti, saugo nuo neurotiškumo. Poreikių tenkinimas lemia atitinkamas emocijas ir „leidžia pasireikšti tokioms charakterio savybėms kaip prieraišumas, savigarba, pasitikejjimas savimi, saugumas“ (Maslow, 2009, p. 100). Taigi gerosioms žmogaus savybėms. Pasak psichologo, pamatinių poreikių tenkinimas nulemia kognityvinius, kognityvinius afektinius, charakterio bruožų, tarpasmeninius ir kitus ịvairius (nepriskirtus minètoms grupèms) reiškinius.

Žmogus, kad atgautų pusiausvyrą, užpildytų trūkumą, nuolat siekia atsikratyti ji veikiančio poreikio. A. Maslow'o teigimu, kadangi dominuoja augimo motyvacija ir nuolatinis poreikių tenkinimo troškimas, žmonès neturi ramybès, nes jų ,patenkinimas sustiprina, o ne silpnina motyvaciją, padidina, o ne sumažina susijaudinimą“ (Maslow, 2011, p. 99). Žmogus nori vis stipriau jausti poreikio patenkinimo malonumą, tad patenkinęs kažką vieną, norès kito ir t. t. Taip, ieškodamas jaudulio, tampa aktyvesnis, nenusiramina. Taigi, kaip kaliniai tenkina savo poreikius, remiantis mokslininko sudaryta poreikių hierarchijos piramide, ką tai duoda jiems kaip asmenybėms. Nuteistasis bando gelbètis turimomis vidinèmis priemonėmis, savo pastangomis, kad nežlugtų psichologiškai veikiant išoriniams dirgikliams, tokiems kaip kalejjimo prižiūrètojų žiaurumas ar nuasmeninimas. Jis priešinasi, kad išliktų, dar turi vidinės motyvacijos, galutinai nesužlugdytas.

\subsection{Fiziologiniai poreikiai - ne tik „valdinis“ maistas}

Esminiai žmogaus poreikiai, kurių nepatenkinus negalima patenkinti kitu, - fiziologiniai. Romano veikèjai, patenkinę geresnio maisto poreikį, tapdavo energingesni, pagerẻdavo jų nuotaika. Prastas kalinių maistas jų nepasotindavo: „Darbas sunkus, o mus žarnokais šeria. (...) mes fabrike kamuojamės kamuojamès, po darbo norètųsi ir paèsti““ (Dostojevskis, 2006, p. 329). Kalinių skundai dèl maisto išsakyti pretenzijoje majorui. Be to, nebuvo maisto ịvairovès, tik duona, kopūstienè, žarnokai ir kogalviai ${ }^{1}$. Maistas normuotas (išskyrus duoną, kuri vienintelè buvo skanesnè ir buvo galima valgyti, kiek norisi), tad

1 Remiantis Lietuvių kalbos žodynu, kogalviai yra gyvulio galūnių ir vidaus organų mèsa (kojos, galva, ausys, uodega, plaučiai, kepenys, širdis); žarnokai - viduriai, žarnos. 
nenuostabu, kad mažai valgę ir sunkiai dirbę vyrai jausdavo alkị. Kalëjimo maistu patenkinti buvo tik laisvejje badavusieji. Be to, A. Maslow'o teigimu, už fiziologinių poreikių gali slypèti ir kiti poreikiai: „Pavyzdžiui, asmuo, kuris mano esąs alkanas, iš tikrujų gali daugiau ieškoti paguodos ar priklausomybės negu vitaminų ar baltymų“" (Maslow, 2009, p. 67). Romane nuteistujų pareikštos pretenzijos kontekstas atskleidžia jų siekị kompensuoti kitus poreikius, o maistas tapo patogiu pretekstu. Kiti žmonių trokštami, bet nepatenkinti poreikiai - tai laisvès ilgesys, veikla (kaliniai nuobodžiavo laisvu nuo darbo laiku), galimybe išsimiegoti ir poilsis (kadangi vasarą dienos ilgesnès, kaliniai daugiau dirbdavo ir mažiau miegodavo).

Turint pinigų buvo galima valgyti savo maistą, jo nusipirkus turguje, už kalejjimo ribų. Bet tokių buvo maža, nes „daugumas valgè valdinị““ (Dostojevskis, 2006, p. 32). Daugiausia tokiu maistu mégavosi bajorai, ị kalèjimą slapta ịsinešę didesnę pinigų sumą. Arba ypatinga proga, kuriai nuteistasis turẻdavo taupyti kiekvieną uždirbtą kapeiką. Pavyzdžiui, vardadienio proga pas virèją užsisakius geresnius pietus, kaliniui paruošiama ,jautienos, žuvies, padaroma sibirinių koldūnų; jis prisièsdavo kaip jautis, beveik visada vienas, retai kada tesikviesdavo draugus ị savo puotą“ (Dostojevskis, 2006, p. 54-55). Kaliniai tai suprasdavo, juk didelei puotai ir vaišèms nèra pinigų, girtą net gerbdavo, laikydavo aristokratu. Pasak A. Maslow'o, žmogų stipriai užvaldžius kokiam nors poreikiui, keičiasi jo filosofija. Kaip pavyzdi psichologas pateikia alkị: jei žmogus labai trokšta maisto, jo utopija bus vieta, kur jo nestinga. „Laisvè, meilè, bendruomeniškumo jausmas, pagarba, filosofija - i viską galima numoti ranka kaip ị nereikalingus“" (Maslow, 2009, p. 68). Taip ir vardadienį švenčiantis kalinys jautè, kad be maisto ir degtinès jam daugiau nieko pasaulyje nereikia. Kitiems kaliniams toks žmogus atrodẻ lyg būtų išpildęs visus savo gyvenimo siekius, todèl ir gerbè. Galbūt jie patys tegalvojo apie alkio patenkinimo poreikị, kaip aukščiausią būties tašką, kurị varduvininkui pavyko pasiekti.

Aleksandras Petrovičius kopūstiene baisèjosi: ,Ją virdavo bendrame katile, šiek tiek uždarydavo kruopomis, ir ji būdavo skysta, liesa, ypač šiokiadieniais. Mane siaubas nukrètè, kai pamačiau, kaip daug kopūstuose tarakonų. O kaliniai i juos nėmaž nekreipé dėmesio“ (Dostojevskis, 2006, p. 33). Pasak 
psichologo D. Myers'o, valgymo ịpročiams svarbūs biologiniai, psichologiniai ir socialiniai-kultūriniai veiksniai. Šiuo atveju veikèją stipriai veikè maisto išvaizda ir kvapas (psichologinis poveikis). Jam, bajorui, buvo sunku tokị maistą valgyti, nes ị kalejjimą atvyko, turèdamas tam tikrus jo aplinkai būdingus kultūriškai suformuotus skonio prioritetus (socialinis-kultūrinis poveikis). Biologinis valgymo poveikis svarbus, siekiant užsitikrinti fizini išlikimą (jei būtų vadovaujamasi vien tuo, žmogus galètų valgyti bet kokị maistą jo nesirinkdamas), vis dèlto „psichologiniai ir socialiniai-kultūriniai veiksniai daro didelę įtaką tam, ką, kada ir kiek valgome“" (Myers, 2008A, p. 588). Romane rašoma, kad riestainių pardavejos ị kalejimą atnešdavo riestainių, kuriuos po dvi kapeikas pirkdavo beveik visi kaliniai. Tai nebrangus būdas įsigyti skanesnio maisto, o riestainiai - saldžiausias desertas, palyginti su liesa kalèjimo kopūstiene. Mokslininkų nustatyta, kad nuo angliavandenių padidejjus serotonino kiekiui, žmonès jaučiasi ramesni (žr. Ten pat, p. 585). Taigi riestainiai pagerindavo ir psichologinę kalinių savijautą.

Romano herojui buvo pasiūlytas būdas, kaip skaniau maitintis. „Akimas Akimyčius pačioj pradžioj, pirmosiomis dienomis, rekomendavo man vieną kalini - Osipą, sakydamas, kad už trisdešimt kapeikų mènesiui jis man kasdien gaminsiąs skyrium valgi, jei jau man toks bjaurus valdinis maistas ir jei aš turèsiąs lèšų valgyti savą“" (Dostojevskis, 2006, p. 91). Taigi pagrindinis veikèjas pasirinko šią geresnio maitinimosi išeiti - valgè turguje pirktą jautieną ir „valdinę“" duoną, o kopūstus - tik tada, kai būdavo labai alkanas, nes jais bjaurèjosi. Turint pinigų, net kalëjime galima pasijusti ne tokiu niekingu žmogumi. Nors už juos perkamu maistu tenkinami elementarūs fiziologiniai poreikiai, kaliniui tai leidžia geriau jaustis. Remiantis A. Maslow’o sudaryta poreikių hierarchijos piramide, patenkinus žemesniuosius poreikius (t. y. fiziologinius - būtiniausius, be kurių visi kiti negalimi), žmogui aktualūs tampa aukštesnieji. Jis skiria gerovè jausmą, sveikatą, energiją, euforiją ir fizinị pasitenkinimą, kaip fizinio pasisotinimo ar persisotinimo maistu (ar kitu fiziologiniu poreikiu) poreikiu tenkinimo reiškinius. Valgymo poreikiui kuriam laikui nusilpus, jis ,užleidžia“ vietą kitiems norams. Tada kyla saugumo poreikis. 
2.2. Saugumo poreikiai - meistrystė ir kita pinigų vertė

A. Maslow'as saugumo poreikių kategorijai priskiria „stabilumą, priklausomybę, apsaugotumą, laisvę nuo baimès, nerimo ir chaoso; struktūros, tvarkos, įstatymo, ribų, stipraus užtarèjo poreikius“ (Maslow, 2009, p. 69). Kadangi analizuojamo romano aplinkoje psichologinius saugumo poreikius patenkinti nelengva, nes jos galimybès kaip tik ribotos, tai nesaugi, nerimo, itampos kupina vieta, išradingi amatą turintys kaliniai saugumą suvokè santykinai užsitikrindami tam tikrą finansini stabilumą. Kalinys negalèjo turèti asmeninès nuosavybės (išskyrus Šventajį Raštą), bet poreikis turèti savo daiktų neišnyko. Kalinys siekè pats apsirūpinti, tad uždirbti pinigai tapo saugumo garantija, suteikiančia galimybę ịsigyti keletą asmeninių daiktų. Kadangi daugelis kalinių negalejjo pakęsti privalomo darbo, nes iš to neturejjo jokios naudos (nepatenkindavo kūrybiškumo, savęs realizavimo, piniginio atlygio ir įvertinimo poreikių), visą savo energiją jie nukreipdavo ị laisvalaikio darbus, vadinamus meistryste, tai leisdavo atsiskleisti jų gabumams. „Be darbo ir be teisètos, normalios nuosavybės žmogus negali gyventi, gadinasi, virsta žveerimi. Ir užtat kalëjime kiekvienas, skatinamas prigimties reikmès ir tam tikro savisaugos jausmo, turẻjo savą meistrystę ir užsièmimą" (Dostojevskis, 2006, p. 25).

Ši veikla - ne tik hobis, bet ir pajamų šaltinis (meistrystės produkciją parduodavo mieste). Kalèjime buvo „,ir batsiuvių, ir kurpių, ir siuvejjų, ir šaltkalvių, ir graverių, ir auksintojų“ (Dostojevskis, 2006, p. 26). Kas nemokèjo amato, išmokdavo jo iš kitų kalinių. Išmoktas amatas, anot A. Maslow'o, patenkina smalsumo poreikị. Meistrystè kalèjime nedrausta, bet neleista turèti darbo ịrankių, be kurių jokia veikla neimmanoma. Tad dirbta paslapčia, o per kratas surastus paslèptus ịrankius atimdavo, taip pat ir pinigus. Bet kaliniai nepasiduodavo pralaimèjimui, jie vèl ịsigydavo įrankius ir tęsdavo darbą. Taip elgtis skatino meistrystės užtikrintas saugumo siekis. Saugumo jausmas formuoja ,stipresnę valią, mėgstama būti atsakingam“" (Maslow, 2009, p. 110).

Savas užsièmimas ,gelbejjo nuo nusikaltimų: be darbo kaliniai suėstų vienas kitą kaip vorai stiklinèje“ (Dostojevskis, 2006, p. 26). D. Myers'o teigimu, darbas apima kelis A. Maslow'o poreikių hierarchijos piramidès lygius. Tai ne tik saugumo (pvz., finansinis stabilumas), bet ir ịvertinimo (pvz., karje- 
ros siekis), savęs aktualizavimo (pvz., kūrybinis darbas) poreikiai. „Dykinëjimas gali atrodyti kaip palaima, tačiau tikslingas darbas praturtina gyvenimą“ (Myers, 2008A, p. 613). Patys pasirinkę meistrystę, nesitenkindami kalëjimo primestu darbu, kaip prievole, žmonès galëjo atskleisti savo individualumą, gabumus, išvengti nuobodaus nieko neveikimo, nukreipti energiją teigiama linkme, o ne leisti kauptis pykčiui, esant izoliuotam kalejjime. Kilus susidomejjimui, nebejaučiama nuobodulio, gérimasi savo meistrystès rezultatu.

Nors už meistrystę gaudavo tik keletą kapeikų, pats pinigų turẻjimas suteikè saugumo ir savarankiškumo galimybę. Kalèjime drausta turèti pinigų, tad jų gavę kaliniai greitai juos išleisdavo arba gerai paslëpdavo, saugodami nuo vagių. Už juos pirkdavo maistą, degtinę, tabaką, baltinius, minkštesnę pagalvę ir kt., žinoma, tai darydavo paslapčia nuo kalejjimo prižiūretojų. Pinigai kaliniams leido pajusti, kad kažką valdo, nuo jų valios gali priklausyti pasirinkimas, kaip juos leisti. „Pinigai yra kaldinta laisvė, užtat žmogui, kuriam visiškai atimta laisve, jie brangesni dešimteriopai. Jeigu tik jie žvanga kišenèje, jis jau pusiau paguostas“ (Dostojevskis, 2006, p. 26). Tai patenkino jų saugumo poreikị, kurio nesuteikè asmenybę varžanti kalèjimo atmosfera.

„Užrašuose iš mirusiujų namų“ kalèjimo vyresnybė svarstè, kam kaliniams reikia pinigų, jei yra viskuo aprūpinti? Atsakymas - jie suteikia galimybę reikšti savo valią. Be abejo, ta valia pasireikšdavo ir nelabai tinkamais būdais: už pinigus gaudavo draustos degtinès, papirkdavo viršininkus ar net puskarininkị, kad nepaisytų nusižengimų kalejjimo tvarkai, užvaldyti pinigų galios jausmo jausdavosi viršesni prieš kitus kalinius. Pagrindinè psichologiné pinigų ịtaka - pojūtis, kad turi kažkam galios. Kalinys ịtikindavo save, kad jo sprendimai yra kažkokios atsakomybės išraiška, ,nors per aguonos grūdą [kalèjimas] panašus ị gyvenimą, nors iš tolo primena šiokị tokị laisvès šešèlị“ (Dostojevskis, 2006, p. 107). Pinigai siejosi su laisve reikšti savo valią. Laisvè, apsaugota pinigų dèka. Leidžiant pinigus patenkintas saugumo poreikis lemia kai kuriuos svarbius charakterio ir tarpasmeninio bendravimo bruožus. Saugumas suteikia „ramumo, pusiausvyros, romumo, dvasios ramybės (priešingai ịtampai, nervingumui, nelaimingumui, jausmui, kad esi apgailètina būtybė)“(Maslow, 2009, p. 109). Be to, lengviau prisitaikoma prie frustracijos, tampama draugiškesniu kitiems kaliniams. 
Pinigai tapatinti su nepriklausomybės poreikiu, vertinami ir laikomi „beveik lygiomis su laisve“ (Dostojevskis, 2006, p. 51). Tik laisvè buvo vertingesnè už pinigus. Jei nuteistasis jų neturẻdavo, būdavo „liūdnas, nesmagus, neramus ir nusiminęs, (...) įmanytų ir vogti, ir ką tik nori daryti, kad tiktai jų gautų" (Ten pat). Jiems nereikejjo daug pinigų, svarbu, kad būtų bent kelios kapeikos. Kalejjime kelios monetos daro didesnę teigiamą psichologinę ịtaką nei dideli pinigai laisveje. Patenkinti fiziologiniai ir saugumo poreikiai užtikrina būtinaji fizini ir psichologini žmogaus išlikimą. Tada pereinama prie psichologinių-socialinių poreikių, kurie augina pačią asmenybę. „Mes augame, kai augimo malonumas ir saugumo nerimas didesni nei augimo nerimas ir saugumo malonumas" (Maslow, 2011, p. 120). Taigi neužstringama patogioje saugumo būsenoje, bet siekiama daugiau - meilès, ịvertinimo ir savęs realizavimo galimybès. A. Maslow'as saugumo poreikị priskiria ribai, kai individas priverstas rinktis tarp saugumo ir augimo proceso. Nuolatinès būtinybės pasirinkti situacijos žmogų pastato tarp saugumo ir augimo: likus prie saugumo pozicijos vyksta regresija, o prie augimo - progresas.

\subsection{Priklausomybės ir meilès poreikiai - draugystė kalèjime}

Patenkinęs saugumo poreikius, asmuo jais neapsiriboja, kyla aukštesnio lygmens priklausymo ir meilès poreikiai. Jis nori būti mylimas ir priimtas, pats mylèti ir priimti kitą. Be abejo, ir išvengti vienatvès bei atstūmimo. Romane idealizuotai aprašoma veikèjų Aleksandro Petrovičiaus ir Alejjaus draugystè - patenkinti priklausomybès ir meilès poreikiai. Alèjus, Dagestano krašto totorius musulmonas, su dviem savo broliais kalèjo už vagystę. Knygos herojui draugystė su šiuo jaunu 22 metų vaikinu teikẻ didelị džiaugsmą. Alèjaus ,ک̌ypsenoj buvo tiek pasitikejjimo, tiek vaikiško paprastumo; didelès juodos akys buvo tokios švelnios, tokios malonios, jog aš visada jausdavau ypatingo smagumo, net palengvejjimo mauduly ir gèloje, kai žiūrẻdavau i jị “ (Dostojevskis, 2006, p. 82). Jis yra vienintelis F. Dostojevskio taip subtiliai aprašytas veikèjas, sukeliantis teigiamų emocijų pagrindiniam personažui (kiti veikejjai ne taip sureikšminti emociniu požiūriu). Alejjui suteiktos geriausios fizinès (šypsena, akys) ir charakterio savybès (pasitikintis, jautrus, 
švelnios širdies, doras, tyras, vengiantis ginčų, gebantis apsiginti, visų mylimas, kuklus, darbštus). Savo meilès teorijoje psichologas Erich'as Fromm'as nurodo būtinybę žmogui susisieti su kitais žmonèmis, kitaip jo egzistencija taptų uždara ir vieniša. Asmuo trokšta priklausyti bendruomenei, priešingu atveju jis nuolat nerimautų. „Būti atskirtam, vadinasi, neturèti jokių galimybių panaudoti savo žmogiškąsias jègas“"(Fromm, 2014, p. 11). Kad to išvengtų, žmogus jaučia meilès poreikị, kurio patenkinimas teikia artumo jausmą. Čia kalbama ne tik apie intymią vyro ir moters meilę, bet apskritai artimo meilę, motinos meilę vaikui ir kt.

Žmogus iš prigimties yra socialus, jam „lemta susisaistyti su kitais“ (Myers, 2008B, p. 478). Burdamiesi i grupes proteviai mokèsi bendradarbiauti, kad išliktų, o priklausydami bendruomenei išmoko prisitaikyti. Igyti ịūdžiai ir poreikis priklausyti išliko iki šių dienų. Tarp žmonių mezgasi draugystė, santykiai tampa gilesni. „Priešingai nei gaivališka aistringoji meilè, draugiškoji meilè yra santūresnè: tai gilus, švelnus prisirišimas“ (Ten pat, p. 478). Jei tarp draugų užsimezga artimas ryšys, juos susieja bendri malonumą teikiantys patyrimai, jų draugystė tik sustiprėja. Draugiška meilè siejo ir romano veikèjus: „Aš laikau Alejų anaiptol ne paprastu žmogumi, laiką, praleistą su juo, prisimenu kaip vieną iš gražiausių visame savo gyvenime" (Dostojevskis, 2006, p. 83). Be to, patenkintas draugiškos meilès poreikis skatina atsiskleisti kitam asmeniui. O patenkintas priklausymo jausmas teikia džiaugsmą. Pasak Antano Paškaus, draugų meilè yra išlaisvinanti. Teologas pabrèžia, kad draugystei būdingas atsiribojimas ir abejingumas išoriniam pasauliui. Minètiems romano personažams maloni draugystė leido atsiriboti nuo kitų kalinių nesutarimų, itampos, slogios nuotaikos. Vis dèlto pažymètina, kad pagyros vienas kitam gali lemti išdidumą, kuris gali būti grèsmingas. Kad taip nenutiktų, būtini bendri idealai. Be žmogaus pastangų, draugiškai meilei išlaikyti reikia ir Dievo pagalbos, „kad galètų palikti maloni ir džiaugsminga“ (Paškus, 1995, p. 96). A. Paškus draugų meilę laiko vaisingiausia iš visų meilès formų, nes jos šaltinis yra pati dieviškoji meilè. Tik tokia patirta meilè leido Aleksandrui Petrovičiui ištarti: „Jis mylèjo mane galbūt taip pat, kaip ir brolius“ (Dostojevskis, 2006, p. 86). Taigi poreikis būti mylimam išsipildè. 
Goriančikovas draugavo ir su Alëjaus broliais: „Jie taip pat, matydami, kad aš vis labiau pamilstu Alèjų, pasidarè man daug meilesni“ (Ten pat, p. 85). Pagrindinis veikejjas per draugiškus santykius su Alèjumi tapo pripažintas ir mylimas jo brolių, buvo priimtas socialinès grupès kaip šeimos narys. Kai asmuo jaučia, kad pritampa prie socialinès grupès, kyla jo savivertė. D. Myers'o teigimu, nepavykus išsaugoti draugystès, apima nerimas, kyla vienišumo, pavydo ir kaltès jausmai, rodoma nepagarba ir agresyvumas tiems, kas įžeidè. Patenkinus prisirišimo ir meilès poreikius intensyvèja tam tikri kognityviniai reiškiniai (tokie kaip demokratiškumas, pagarba žmonèms, draugiškumas) ir ugdomi atitinkami charakterio bruožai (pvz., malonumas, geraširdiškumas, užuojauta, nesavanaudiškumas, sveikas dosnumas, nuoširdumas) lieka mažiau veidmainystės ir apsimetinejjimo ${ }^{2}$. Pagerẻja ir tarpasmeniniai santykiai, nepagrịstą priešiškumą keičia draugiškumas ir empatija. Patị Alèjų broliai mylëjo kaip vaiką, nes jis buvo jauniausias, lyg paguodos šaltinis, atrama kalèjimo niūrybejje. Esant draugiškiems santykiams, atrodo, kad ir kalèjimo atmosfera nebe tokia slegianti. Anot filosofijos daktarès Aušros Malkevičiūtès, nagrinejjusios F. Dostojevskio mąstymo pasaulèvaizdį, ,tiesiogiai bendraudamas su kitu žmogumi, asmuo atveria savo dvasines kūrybines galias (glūdinčias prigimtiniame prade) ir apibrèžia savo istorinio buvimo lauką, kuriame jo egzistavimas igauna prasmę bei istorinę vertę" (Malkevičiūtè, 2003, p. 137). O susvetimejjimas tampa visos tautos dvasinio smukimo motyvu. Draugystẻ ir meilè kitam tampa egzistencine išlikimo būtinybe.

Išeidamas iš kalèjimo Alëjus verkdamas dèkojo už tai, kad Aleksandras Petrovičius išmokè ji skaityti (skaitė Naujaji Testamentą) ir rašyti (tai darè paslapčia, nes turèti popieriaus drausta). ,Tu man tiek padarei, tiek padarei, - kalbejjo jis, - kad nei tèvas mano, nei motina tiek nebūtų padarę: tu mane žmogum padarei, Dievas tau atlygins, o aš tavęs niekad neužmiršiu..." (Dostojevskis, 2006, p. 87). Dẻkojama ne už suteiktus naujus skaitymo ir rašymo ịgūdžius, bet už broliškos meilès patirtị. Anot E. Fromm'o, broliška meilè yra „,fundamentaliausioji meilès rūšis, visų kitų meilès rūšių pagrindas“" (Fromm, 2014, p. 38). Remdamasis Šventojo Rašto pavyzdžiais, psichologas nurodo, kad broliška

2 Bruožai priskirti remiantis A. Maslow’o „Kai kurių pamatinių poreikių patenkinimo smarkiai nulemtų reiškinių“" sąrašu (žr. Maslow, 2011, p. 107-110). 
meile mylimas kiekvienas žmogus (plg. „Mylèk savo artimą kaip save patį“ [Mt 12,31]), nesvarbu, jis bejègis, vargšas ar svetimas. Broliškos meilès sąvoka apima atsakomybę, rūpestį, pažinimą, pagarbą kiekvienam žmogui ir norą padèti. Nors šie veikejjai buvo skirtingi (vienas - bajoras, o kitas - nè skaityti nemoka), tai netrukdè reikštis nuoširdžiai artimo meilei. Tokia meilè pagrissta supratimu, kad žmonès yra lygūs. „Talento, intelekto, pažinimo skirtumai yra nereikšmingi, palyginus su žmogiškumo esme, bendra visiems žmonėms““(Ten pat). Skirtinga gyvenimo patirtis juos kaip tik ir suartino. Jaunasis herojaus draugas patyrė, koks rūpestingas, nesiekiantis naudos yra Aleksandras Petrovičius, kai mokė ji skaityti ir rašyti. Už tai Alëjus savo mokytoją gerbė. Jie nebematė vienas kito socialinių skirtumų, tik jautė artimo meilę.

F. Dostojevskis kalëjime turèjo ị romano veikèją Alëjų panašų draugą, vardu Ali, 26 metų. Jis kalëjo drauge su trimis savo broliais. Nors informacijos apie ši asmenį šaltiniuose nedaug, žinoma, kad rašytojas ji mylëjo kaip sūnų ir mokè pažinti raštą. ,Jeigu kas būtų sumanęs skriausti mokytoją, nežinia, ką broliai tokiam niekšui būtų padarę“ (Inis, 1999, p. 88). A. Malkevičiūtės teigimu, meilę rašytojas suvokè kaip žmogaus būties jègą. ,Dèl šios galios poveikio žmogus apčiuopia prigimtini (...) pradą savyje, jis išsilaisvina nuo vergavimo egoistiniams troškimams bei polinkiams, atsiveria kūrybiškam santykiui su gamta, žmogumi, Dievu“ (Malkevičiūtè, 2004A, p. 73). Harmoninga žmogaus būtis galima tik palaikant ryši su metafizinèmis prigimties galiomis.

\subsection{Ivertinimo poreikis - pasitikejjimas kaliniu}

Kitas asmens augimui būtinas poreikis - ịvertinimas, siejamas su saviverte, pripažinimu ir pagarba. A. Maslow'as įvertinimo poreikius skirsto ị dvi grupes. Pirmoji susijusi su galiomis ir pasiekimais, antroji - su reputacija ir prestižu. Pastebima, kad antrajai grupei priskiriamas ne tik veikla pelnomas ịvertinimas, bet ir žmogaus orumo bei pritarimo jam siekis, kurie glūdi prigimtyje ir tam žmogaus veikla neturi jokios įtakos. Tai reiškia, kad pripažinimo „užsidirbti““ nereikia, žmogus turi būti vertinamas už tai, kad tiesiog yra žmogus. „Užrašuose iš mirusiųų namų“ pasitikèjimas kaliniu atsiskleidžia dviem atvejais, kai viršininkas be kareivių palydos įeina ị kalejjimo teritoriją ir kai kaliniams leidžiama vieniems, be prižiūrètojų melstis cerkvèje. 
Paprastai kalëjimą prižiūrintys kareiviai nerimaudavo, kad kaliniai jų neužpultų ir nesužalotų. Kaliniai žinojo, kad jų bijomasi ir tai skatino jų narsą. Vis dèlto „pats geriausias viršininkas kaliniams kaip tiktai yra tas, kas jų nebijo. Ir apskritai, (...) jiems patiems daug maloniau, jeigu jais pasitikima“ (Dostojevskis, 2006, p. 70). Kaliniai netrokšta ịvaryti baimès, jiems svarbus supratimas, kad ir jie yra žmonès, kuriuos kalejjimo aplinkos žiaurumas tik gadina, o ne ugdo žmogiškumą. Parodytas pasitikẻjimas leidžia patenkinti įvertinimo poreikị. „Savęs vertinimo poreikio patenkinimas suteikia pasitikejjimo savimi, savo vertès, jègos, pajègumo, adekvatumo, buvimo naudingam ir reikalingam pasaulyje jausmą“ (Maslow, 2011, p. 77). A. Maslow'as perspejja, kad tikrasis įvertinimas - tai kitų pagarba, o ne išorinè šlovė ar pataikavimas. Negalėdamas patenkinti ịvertinimo poreikio asmuo jaus nevisavertiškumą, silpnumą, bejègiškumą, kurie lemia neurozes.

I kalèjimą be kareivių palydos patikrinti atèjęs kalèjimo vyresnybès atstovas kalintiesiems paliko gerą ịspūdị. „Toksai bebaimis lankytojas visada sužadindavo pagarbą sau, ir jei net iš ties galejo atsitikti kas blogo, tai prie jo nebūtų atsitikę“" (Dostojevskis, 2006, p. 70). Kai žmogus jaučia, kad ji gerbia, stipreja demokratiški ịsitikinimai, tai „bebaimè ir realistinè pagarba tiems, kurie jos verti“" (Maslow, 2011, p. 110). Tai abipuse pagarba, kurią skatina pasitikẻjimas kitu žmogumi. Kalèjimo vyresnybės atstovas pasitiki kaliniu, tiki, kad šis jo nesužalos, taip pelno pagarbą. Ir kalinys, tarsi atsidèkodamas už parodytą pasitikèjimą, nebesiima kenkèjiškų veiksmų, nurimsta, pakyla jo asmeninè savivertè. Tikslingas pasitikèjimas kaliniu gali tapti prevencine nusikaltimų nuteistujų ar sargybinių atžvilgiu priemone. Šis trumpas gyvenimo kalèjime epizodas atskleidžia, kad ir nuasmenintas žmogus vertas pasitikèjimo, tereikia suteikti jam galimybę atskleisti savo žmoniškumą.

Pasitikejjimą nuteistuoju atskleidè ir suteikta galimybè be sargybinių melstis šventoveje. „Man labai malonu būdavo, kai rytą, pašalusia iš po nakties žeme, mus varydavo su užtaisytais šautuvais į Dievo namus. Varovai, beje, ị cerkvę neidavo“, - personažo Aleksandro Petrovičiaus mintimis dalijasi F. Dostojevskis (Dostojevskis, 2006, p. 291). Šiuo veiksmu romano autorius tarsi siekia parodyti, kad kaliniu, kuris yra cerkveje, galima pasitikèti. Tai pabrèžia ryški vaizduojamo epizodo priešybè: lauke kalinius lydi šautuvus i 
juos nukreipę prižiūrètojai, o cerkvèje jie paliekami be priežiūros. Tikima, kad būdamas Dievo akivaizdoje nepadarys nieko blogo. Beje, kaliniams i maldos namus buvo galima eiti tik per gavènią, kad atliktų išpažintị, ir šv. Velykų rytą - ị šv. Mišias. Cerkvejje „likę vieni, nors ir žvangindami geležiniais pančiais, kaliniai valandèlę pasijausdavo beveik laisvi“ (Inis, 1999, p. 91). Bent dvasiškai. Žmoniška tai, kad kalejjime, atėmus visas kalinio laisves, jam palikta tikejjimo laisvė ir išpažinimas. Tai ir psichologinès ịtampos pašalinimas trumpam, kai nesikišama ị asmens ir Dievo santykị, nejaučiama prižiūrètojo kontrolè. Cerkvejje kaip tikintysis jis nediskriminuojamas, nors esamas socialinis statusas kitoje aplinkoje ji žemintų. Šventajame Rašte Jèzus pasigaili svetimaujančios moters (žr. Jn 8, 3-11), tai atleidimo pavyzdys, rodantis, kad žmogus, pats būdamas nusidejejlis, neturètų smerkti kito. Taigi ir kalinys vertas pagarbos, i ji „,sviesti akmens“ nereikètų. Bažnyčioje nebeskirstoma ị kalinius ar laisvuosius, visi tampa lygūs prieš Dievą.

Žvelgiant plačiau iš krikščioniškosios perspektyvos, kaliniai verti pagarbos, nes juose išryškejja Jėzaus veidas, kuris „savo Bažnyčioje yra daugeliu būdų: savo žodyje, savo Bažnyčios maldoje, (...) vargšuose, ligoniuose, kaliniuose, sakramentuose, kurių steigėjas Jis yra, Mišių aukoje ir kunigišką tarnybą vykdančiuose asmenyse, bet „pirmiausia eucharistiniais pavidalais“ (Katalikų Bažnyčios Katekizmas, 2015, Nr. 1373). F. Dostojevskis atskleidžia, kad vadovaujantis krikščionišku mokymu su žmogumi pagarbiai galejjo elgtis net ir griežčiausi prižiūrètojai. Nedrista sukurti tokios kalejjimo tvarkos, kuri galutinai dvasiškai žmogų sužlugdytų, jam palikta praktikuoti religiją. Popiežius Pranciškus vienoje Bendrosios audiencijos katechezèje apie ligonius ir kalinius primena, kad Jėzus ragino neteisti. Kalinys yra mylimas Dievo nepaisant to, ką yra padaręs. Prarasta laisvè yra didžiausia nuteistojo netektis. „Prie to pridèkime degradaciją, kylančią dèl tų žmonių gyvenimo sąlygų, kur dažnai stokojama žmoniškumo, - tokiu atveju krikščionis turi jausti pareigą padaryti viską, kad atkurtų jo orumą“ (Pranciškus, 2016-11-09). Galima teigti, kad net trumpa cerkvejje be prižiūrètojų praleista akimirka kaliniams ịkvepia pasitikèjimo, taip parodoma pagarba žmoniškumui ir religijai, trumpas laisvės potyris leidžia pasijusti oriu. 
2.5. Savęs aktualizavimo poreikis - teatrinè veikla

Aukščiausias asmens poreikis, remiantis poreikių piramide, - išreikšti savo individualybę. A. Maslow'as tai vadina savęs aktualizavimu - unikalių gebejjimų realizavimu. Kiekvienas žmogus save išreiškia skirtingai: vienas yra puikus menininkas, kitas - mokslininkas, trečias - sportininkas ir t. t. Romane išryškèja keturi savęs aktualizavimo poreikio raiškos būdai, realizuoti teatrinèje veikloje - teatro kritikas, dekoracijų kūrèjai, muzikantai ir aktoriai.

Trumpai apžvelgiant kalëjimo teatro kontekstą, galima paminèti, kad vaidinimas prasidejo trečią šv. Kalėdų dieną, pasirodymai vyko keletą dienų. Kalejimo vyresnysis puskarininkis tam neprieštaravo, jeigu kaliniai gerai elgsis. Svarbu pabrèžti, kad miestas, kuriame buvo kalèjimas, teatro neturèjo, tad visiems buvo įdomu, ką parengs kaliniai. Vaidinimą galèjo ateiti pažiūrèti visi norintieji už simbolinę auką išlaidoms atlyginti ir dalyviams paskatinti: aukojo kas kiek norejo. Teatras priminè liaudies teatrą, vaidino 15 kalinių, grojo 8 asmenų orkestras. Vaidinimas - trijų dalių: dvi pjesės ir pantomima (vyravo komedijos žanras). Kostiumams ir dekoracijoms naudojo tai, ką patys turejo ar pavyko gauti mieste. Teatras ịrengtas kazarmoje, nors ir susispaudę, kaliniai buvo laimingi ir nekreipè dèmesio ị vietos trūkumą. Žiūrovai nebuvo reiklūs, vaizduotė užpildè varganą kalëjimo aplinką.

F. Dostojevskis Goriančikovui suteike teatro kritiko funkciją. Šiame vaidmenyje jis galèjo atskleisti savo išmanumą. ,I mane iš dalies žiūrejjo kaip i vertintoją, žinovą, buvusị dar ne tokiuose teatruose; matè, kad Baklušinas per visą tą laiką tarèsi su manimi ir pagarbiai elgèsi. (...) troško dabar, kad aš pagirčiau jų teatrą, ir be jokio savęs žeminimo nuleido mane ị geriausią vietą“ (Dostojevskis, 2006, p. 197-198). Jis, kaip buvęs bajoras, inteligentas, galèjo suteikti laukiamą atgalini ryši aktoriams po pasirodymo, kuris būtų kitoks nei kultūriniame gyvenime nedalyvavusių kitų kalinių. Pagrindiniam herojui, intelektualui, jaučiama pagarba, pagerèja tarpasmeniniai santykiai, jis jaučiasi įvertintas. Pastebima tų pačių knygos personažų charakterių teigiama transformacija. Pasak A. Malkevičiūtès, tai prigimtinio ir individualaus (egoistinio) pradų sąveika, lemianti vidinius prieštaravimus. „Žmogaus prigimtinio prado raišką F. Dostojevskis apibūdina solidarumo, atviraširdiš- 
kumo savybėmis, slopinančiomis egoistinio prado veikimą" (Malkevičiūtė, 2003, p. 136-137). İkalintujų domėjimasis Aleksandro Petrovičiaus atsineštaja kultūrine patirtimi skatina labiau pažinti jị patị kaip asmenị, nesiekiant asmeninès naudos bendraujant.

Vienas kalinių, vardu Baklušinas, aktoriaus vaidmenį atliko nepriekaištingai. „Jis suvaidino nuostabiai apgalvotai, prasmingai. Matei, kad jo įsimąstyta ị kiekvieną frazę. İ kiekvieną savo judesįi“ (Dostojevskis, 2006, p. 201). Goriančikovas, matęs tą pačią pjesę Maskvos ir Peterburgo teatruose, nusprendè, kad profesionalūs aktoriai vaidmeni atliko silpniau. O po pasirodymo „visas veidas jam švytėjo laime, tikras ịkvėpimas spindejjo akyse“ (Ten pat, p. 202). Visi, kurie teatre atliko tam tikras funkcijas (gal kiek mažiau Aleksandro Petrovičiaus), leido pasireikšti savo kūrybiniams gebejimas, kurie yra neatsiejama saviaktualizacijos dalis. A. Maslow'as kūrybiškumą laiko esminio žmoniškumo sinonimu ir apibrèžiama charakteristika. Jis skiria ,iš ypatingo talento kylantị kūrybiškumą nuo kūrybiškumo aktualizuojant save“ (Maslow, 2011, p. 219). Antrasis būdingas visų žmonių kasdienei veiklai. Taigi ir kaliniams. Nesvarbu, kad nesi profesionalus dailininkas, muzikantas ar aktorius, vis tiek gali kūrybiškai išreikšti save ir paprastuose dalykuose. Psichologas pabrěžia, kad kūrybiškai galima daryti bet ką, tarkim, tvarkyti namus. Pavyzdžiui, kalejjimo teatro uždangos dažytojai galèjo pasijusti tikrais dailininkais ir išreikšti savo meninius gebejjimus meniškai tapydami ant kuklios sudurstytos drobės. Mokslininkas pastebi, kad realizuodamasis kūrybiškai žmogus tampa panašus i kūrybingą vaiką (tam būtinos laimingumo ir saugumo sąlygos). Vaikiškam kūrybingumui būdinga suvokimo laisvè, nevaržomas spontaniškumas ir išraiškingumas. Net ir tai išryškèjo kaliniuose, kurie „kaip vaikai džiaugèsi mažiausiu pasisekimu, net fantazavo visaip“ (Dostojevskis, 2006, p. 191). Matome, kokie teigiami psichologiniai pokyčiai gali vykti su kaliniais, kuriems suteikta šiek tiek laisvès kurti ir atsiskleisti.

Psichologè Junona Almonaitienè, tyrinejjusi kūrybiškumo procesus, skiria motyvaciją, kuri apima asmens elgesị, vertybes ir interesus. Ji gali būti vidinè, kai veikla užsiimama, nes ji teikia malonumą, ir išorinè, kai tai daroma dèl apdovanojimo ar atlyginimo. Motyvacinès paskatos (malonumas, ịvertinimas, pinigai ir kt.) gali būti suprantamos nevienodai, vieniems ta pati 
paskata bus išorinè, kitiems - vidinè. Žinoma, kūrybinè veikla gali apimti ir abi motyvacijos rūšis. Tyrimai „parodè, kad vidinè motyvacija kūrybiškumui yra palanki, o išorinè - ne“ (Almonaitienè, 1997, p. 70). Vidinè motyvacija lemia sèkmingesnę veiklą. Kalëjime iš esmès vyravo vidinè motyvacija. Štai teatro orkestro sudètyje buvo aštuoni instrumentais groję kaliniai, labiausiai žavejo balalaikininkų atlikimas: „Tonas, skonis, pats grojimas, elgesys su instrumentu, melodijos perteikimo charakteris - visa buvo sava, originalu, kalèjimiška" (Dostojevskis, 2006, p. 200). Akivaizdu, kad savitumą nulèmė vidinè motyvacija, kai veikiama ne iš pareigos.

Patenkintas savęs aktualizavimo poreikis kaliniams suteikia turtingesnių emocinių potyrių. Pastebimas ryškus kontrastas tarp kalejjimo realybès ir to, ką gali teikti pozityvaus įvykio galimybè. Knygos autorius tai atskleidžia kaip bejègiškumo ir pasididžiavimo jausmų priešpriešą.

„Isivaizduokite kalèjimą, geležinius pančius, nelaisvę, daugybę liūdnų metų prieš akis, gyvenimą, vienodą kaip vandens lašai rūškaną rudens dieną, - ir staiga visiems prispaustiems ir surakintiems žmonėms leido valandèlę atsiskleisti, nusigiedryti, užmiršti slogų sapną, surengti tikrą teatrą, ir dar kaip surengti: kad visas miestas turètų kuo didžiuotis ir stebètis - aure, ką gali mūsų kaliniai!“ (Dostojevskis, 2006, p. 202-203).

Teigiamų emocijų sustiprejjimu po vaidinimo F. Dostojevskis akcentuoja, jei žmogui leidžiama save kūrybiškai išreikšti, keičiasi ir jo dorovė, bent trumpam. Jis net nurimsta: „Visi kažkaip neịprastai patenkinti, net kaip ir laimingi, ir užmiega ne taip, kaip visada, o beveik ramia dvasia“ (Dostojevskis, 2006, p. 211). A. Maslow'o teigimu, patenkinus savęs aktualizavimo poreikị geriau pakeliama vienatvė, kuri nebekelia psichologinės kančios, net kyla privatumo poreikis. Žmonėms ,nesunku likti nuošalyje, jie santūrūs, ramūs, nesudrumsčiami, tad asmenines nesèkmes jie moka sutikti ramiai“ (Maslow, 2009, p. 197). Galima spèti, kad ir nuteistieji po vaidinimo nusiramino, kol neišblèso patirtas pasitenkinimas. İdomu, kad savęs aktualizavimas leidžia priimti save, kitus ir gamtą, susitaikyti su trūkumais ir silpnybemis, atsisakyti idealizavimo. Kartu jaučiama atsakomybè dèl ,savo trūkumų, kuriuos įmanoma pataisyti, kaip antai tingèjimas, nerūpestingumas, kantrybės neturèjimas, kitų skaudinimas“ (Ten pat, p. 193). Ši mintis antrina F. Dostojevskiui, 
pabrèždama, kad save aktualizuojantys žmonès puoselèdami krikščioniškąsias dorybes auga, stengdamiesi įveikti ydas, silpsta ir vidiniai konfliktai.

Šiek tiek nukrypstant i poreikių tenkinimo kontekstą galima paminèti, kad save aktualizuojantis žmogus jaučiasi autonomiškas ir gebantis priimti sprendimus, tvarkytis gyvenimą. Tarsi kitu žvilgsniu žvelgiama ị tikrovę, patiriamas naujumas jaudina emociškai. Bet tai vyksta jau ne kalèjimo sąlygomis, kur asmuo ribojamas griežto režimo reikalavimų ir uždaros erdvès. Nuolat save aktualizuojantis žmogus labiau džiaugiasi gyvenimu nei tas, kuris tik retkarčiais turi galimybę save išreikšti. Teatrinė veikla kaliniams buvo tik laikina saviaktualizacijos galimybè. Jie, pritaikius A. Maslow'o išvadas, patyrẻ trumpalaiki pasisekimą, pasiekė viršūnę, išgyveno triumfą. Tačiau, kaip matome, tai davė gerų psichologinių rezultatų. Darydamas esminę išvadą apie savęs aktualizavimo poreikio patenkinimą, aukščiausiu pasiektu rezultatu mokslininkas laiko dichotomijų ịveikimą: „Daugelis priešybių, kurios laikytos esminėmis, susilieja, susilydo sudarydamos vienybę“ (Maslow, 2009, p. 217-218). Tai id, ego ir superego bendradarbiavimas rodo, kad žmogus yra psichologiškai sveika asmenybè.

\section{Psichologinė laisvès samprata kalèjime}

Neturint tikros laisvès, ji sukuriama. Nuteistieji laisvę jautė per laiko (praeitis, ateitis, sustojęs laikas), ritualinio skaičiavimo ir erdvès sampratas. Pačiam F. Dostojevskiui laisvè buvo tiek jo gyvenimo, tiek kūrybos varomoji jèga: „Asmenybės laisvè, protestas prieš žmogaus pažeminimą yra jo [rašytojo] pagrindine „,idejja-jausmas“, kuri, atrodo, gimè kartu su juo“ (Červinskienè, 2004, p. 29). Kalèjime ieškota psichologinių būdų, kaip pajusti laikinai „ikalintą“ laisvę, išsaugoti viltị sulaukti tikrosios laisvės po katorgos. Kalinių sąmonèje kurtas laisvès paveikslas buvo „laisvesnis“ nei tikroji laisvė. Taigi ji idealizuota, atrodè vertingesnè nei iki kalejjimo turètoji laisvès pajauta, tarsi išèjęs bus laisvesnis nei buvo iki nuteisimo.

Kaliniai gyveno ne esamuoju kalejjimo laiku, jie jaute „pakaitinį“ laiką, kai mintimis nusikeliama ị praeitị, ateitị, kartais laikas kalèjime apskritai sustoja. Taip jie pasijaučia psichologiškai laisvi, galintys savo laisvę valdyti. 
Pirmasis būdas pabègti nuo dabarties laiko buvo gyvenimas prisiminimais, savo gyvenimo iki kalèjimo istorijų pasakojimas. Kai kas net mėgavosi pagražindamas pasakojimus, už ką buvo nuteistas. Kitas laisvės suvokimas laiko atžvilgiu apima ateities svajas. Kaliniai sakydavo: „Ogi šit palauk tik, duos Dievas, atbūsiu savo laiką, tai tada..." (Dostojevskis, 2006, p. 106). Arba svajodavo pabėgti iš kalejjimo ir taip palengvinti slegiantị sunkumo skausmą. Laisvès troškimas ir patiriamas psichologinis sukaustymas verčia žmogų veikti taip, kad jis rizikuodamas imsis bet kokių priemonių, kad nusikratytu kančios. Vis dèlto rizikuodavo tik vienas procentas kalinių. O nedrịstantieji bėgti bent mintimis pagyvendavo laisvėje, kurdami neišpildomą pabėgimo ị laisvę planą. Taigi svajonès suteikia galimybę kurti ateities vizijas, kurios yra malonios ir bent mintyse išlaisvina iš esamos padeties. Psichologijoje laisvė nusakoma kaip ,galimybès troškimas, išlaikantis ateities ženklą“ (Būgaitè, 2005, p. 194). Taip daro ir kaliniai - jie viliasi, kad išèję ,atsigriebs“ už nelaisveje prarastus metus. Gyvenimo „dabar“ nèra, jis visas projektuojamas i ateitị laisveje. Trečiasis laiko suvokimas, kai kaliniams laikas tarsi sustoja, jiems atrodo, kad atbuvę bausmę grịš ị tą patị laiką kaip iki kalinimo: ,I dvidešimtmeti jis žiūri kaip i porą metų ir visiškai tiki, jog kai išeis iš kalèjimo penkių dešimčių metų, tebebus toks pat jaunas, kaip dabar, būdamas trisdešimt penkerių. „Pagyvensim dar!“ - taip jis galvoja ir atkakliai veja nuo savęs šalin visas abejones ir kitas ịkyrias mintis“ (Dostojevskis, 2006, p. 127). Pastebètina, kad nuteistasis nepripažista laiko tẻkmès ir kalèjimo dabarties, kuri jam nemaloni. Kalinys psichologiškai išstumia esamojo laiko suvokimą, o kalèjime praleistas laikas neịskaičiuojamas ị gyvenimą.

Kita laisvès samprata - ritualinis kalejjimą juosiančios tvoros stulpų skaičiavimas. F. Dostojevskio neįvardytas veikejjas kasdien pažymėdavo stulpą tvoroje, kad vaizdžiai matytų, kiek dienų praleido kalëjime ir kiek dar liko iki laisvès (tvoros stulpų skaičius atitiko jo kalinimo dienų skaičių). Literatūros tyrinètoja Elena Červinskienè ši bevardị tapatina su pačiu romano autoriumi: „Jis suskaičiavo kiemo tvoroje apie pusantro tūkstančio stulpų. Jam čia teks išbūti ketverius metus, maždaug 1460 dienų. Tvora - jo kalendorius. Dostojevskis kasdien pažymi stulpą - šitaip geriau matyti, kiek liko nelaisvès dienų“ (Červinskienè, 2004, p. 71). Romane minima, kad sužymèjęs kurią 
nors tvoros sieną, veikèjas patirdavo džiaugsmą. Kasdien atliekamu veiksmu pažymèta laisvė tapo apčiuopiama. Vizualus laisvès matymas leido jausti vidinị pasitenkinimą.

Laisvès samprata erdvès aspektu igavo begalybès pilnumo potyrị. Erdvė igavo dvi formas - „siaura - platu“ ir „sava - svetima“. „Siaura - platu“ priešprieša matoma kalèjimo ir fabriko, kuriame dirbo, erdvèse. Dalis kalinių kartu su Aleksandru Petrovičiumi dirbo plytų fabrike sunkiausią iš visų knygoje aprašytų darbų, bet jautė dékingumą už tai, kad yra toliausiai nuo kalèjimo - gražioje Irtyšiaus upès pakrantèje:

„Darbe kuris nors staiga susimąsto, ịremia žvilgsnị ị mėlynuojantị tolį, kur nors tenai, anapus Irtyšiaus, kur prasideda neaprépiamos lygumos, kur traukias bent per pusantro tūkstančio varstų laisva kirgizų stepé; pamatai, kaip atsidūsta kas nors giliai giliai, visa krūtine, lyg, rodos, traukte traukia žmogų kvėptelti tuo tolumu, laisvu oru ir palengvinti juo prislègtą, sukaustytą dvasią" (Dostojevskis, 2006, p. 285-286).

Erdvė kalëjime ir Irtyšiaus pakrantẻje kontrastavo „siaura - platu“ perspektyvoje: kalèjime - ankšta fiziškai ir psichologiškai, daug žmonių ir sunkių minčių; pakrantejje - negyvenamos stepės, platus pasaulis, šviesios mintys ir ramybè. Natūralu, kad nuteistieji ten psichologiškai šiek tiek nurimdavo, pasijusdavo laisvesni, nepaisant patiriamo nuovargio dirbant. Ši erdvè tapo laisvès simboliu. Kalinys jautè ryši su beribiais vietovès toliais, kurie teikè palaimą. „Betarpišką žmogaus ir jị supančio pasaulio ryṣ̨̌ F. Dostojevskis suvokia kaip asmens vidinio saugumo, moralinio tobulejjimo, dvasinio augimo sąlygą“" (Malkevičiūtè, 2004B, p. 96). Gamtos darna teikè žmogui pusiausvyrą psichologiniu požiūriu. „Sava - svetima“ erdvės priešpriešą atskleidžia gyvenimo tikrovės suvokimas. Kaliniai sava erdve vadino gyvenimą iki kalèjimo, kuriame turejo savų sumanymų, veiklos, vilčių. O svetima - patị kalèjimą, kurio gyvenimą laikè netikru: „Kiekvienas katorgininkas jaučia, kad jis yra ne namie, o tartum svečiuose“ (Dostojevskis, 2006, p. 127). Palyginimas, kad kalejjime esama tarsi svečiuose, yra aliuzija ị trumpalaikiškumo momentą: svečiavimasis yra trumpalaikis dalykas, juk visada grị̌tama namo, kur viskas sava, jautiesi gerai. Tad ir romano veikèjai nepraranda vilties grịžti namo, laukia tikrosios laisvès, kaléjimas nèra jų galutinè stotelè. 
Su psichologine laisvès samprata persipina ir teologinè perspektyva. Laisvė lyginama su Jėzaus prisikèlimu. Tai aukščiausia romane minima laisvès forma. Romano pabaigoje pagrindinis personažas išeidamas iš kalëjimo atsisveikino džiaugsmingu palyginimu: „Taip, su Dievu! Laisvė, naujas gyvenimas, prisikèlimas iš numirusiųjų... Kokia graži akimirka!“” (Ten pat, p. 382). Tiesa, tai jau tikroji laisvè, tačiau kai kalejjimo aplinkoje psichologinè laisvė buvo tik tariama, patirta išsvajotoji laisvè prilygsta amžinybès laisvei - nuo kančios ir žemiškojo vargo. Kalinys džiaugiasi ištrūkęs iš kalèjimo kančios. F. Dostojevskis ịprasmina kalinio kančią ją nutraukdamas prisikèlimo metafora, kai viso romano siužetas vystèsi „mirusiųų namuose“. Filosofijos daktarè Elena Būgaitè laisvę gretina su teologine viltimi. Senajame Testamente laisvé siejama su Dievo pažadu, o Naujajame - su prisikèlimu. „Tai asmens egzistencijos prasmè prisikèlimo šviesoje, t. y. surasta toje dinamikoje, kurią vadintume Kristaus prisikèlimo ateitimi““ (Būgaitè, 2005, p. 194). Kyla klausimas, kokia buvo kalinio egzistencijos prasmė prieš išeinant ị laisvę, prieš ,prisikèlimą،"? Pasikeisti į gera už blogą poelgị buvojant neigiamoje kalejjimo aplinkoje? Žvelgiant psichologiniu aspektu neatrodo, kad tai buvo imanoma patiriant asmenybès neigimą, regresiją, pažeminimą, bausmes kalèjime. Tačiau kalinio dvasinis tvirtumas tampa jo egzistencijos prasmingumu ir tikèjimo branda.

\section{Darbas, kaip būdas užsimiršti}

Analizuojant meistrystę, minèta, kad kaliniai nemėgsta darbo, nes jis yra priverstinis ir sunkus. Tai ne tas darbas, kuriuo save realizuotumei, tačiau Aleksandrui Petrovičiui darbas buvo išsigelbejjimo priemonè, patiko jam dèl keleto priežasčių. Prieš pradẻdami analizuoti, pažvelkime ị kitas veikèjo mintis apie neigiamą darbo aspektą. Veikejjas džiaugiasi, kad darbas kalejjime nėra betikslis, pavyzdžiui, ,,pilstyti vandenị iš vienos réčkos ị kitą, o iš tos vèl i pirmają" (Dostojevskis, 2006, p. 31). Beprasmis darbas, kalinio nuomone, verčia jausti pažeminimą, gèdą ir bausmès kančią. Tokie jausmai gali lemti nuteistojo troškimą nusižudyti. Tačiau neneigia, kad priverstinis darbas kalejjime visiškai nesvarbus. Kilusias savidestrukcines mintis apie priverstinị 
darbą, kaip bausmę, galima paaiškinti, remiantis prancūzų istoriko ir filosofo Michel'io Foucault'o mintimis, kad žmogaus kūnas kalèjime traktuojamas kaip instrumentas, kuri galima ne tik uždaryti, bet ir bausti darbu, siekiant atimti ir valdyti jo laisvę, t. y. neleisti jaustis viduje laisvam net kalejjime... „Taip baudžiamas kūnas patenka ị tam tikrą suvaržymų ir apribojimų, įsipareigojimų ir draudimų sistemą. Fizinè kančia, paties kūno skausmai nebėra sudedamieji bausmès elementai“" (Foucault, 1998, p. 18). Bausmès objektu tampa siela ir jos pavergimas žalojant psichiką.

Pirmoji aplinkybė, skatinusi Aleksandrą Petrovičių eiti ị darbą, buvo siekis nesijausti naujoku, ị kurị senbuviai žvelgia su neapykanta. Jis sako: „Visa tai tiek mane iškankino, jog aš jau pats norejjau greičiau ị darbus, kad tik greičiau išpažinčiau ir išragaučiau visą savo negando pilnị, pradèčiau gyventi taip pat, kaip ir jie visi“ (Dostojevskis, 2006, p. 90). Psichologo Aleksandro Jacikevičiaus teigimu, asmeniui susidūrus su grupe, grupès poveikis jam yra didesnis. Tad igyti pripažinimą sudètinga, ypač esant neigiamam nusiteikimui naujo kalinio atžvilgiu. Vienas iš trijų tarpasmenybinių žmogaus poreikių, skatinančių burtis ị grupę, yra ịsitraukimo siekis, kuris „pasireiškia siekimu nustatyti ir palaikyti pasitenkinimą teikiančius santykius su kitais asmenimis“ (Jacikevičius, 1995, p. 33). Kiti poreikiai - kontrolès ir meilès. Taigi kalinys siekia pritapti prie kitų grupès narių parodydamas, kad gali dirbti lygiai su kitais. Jo tapatinimosi su grupe priemone tampa veikimas, o ne žodinis bendravimas. To priežastis - šiurkštus Aleksandro pasitikimas, privertęs jị užsisklęsti savyje. Darbas yra visus nuteistuosius vienijanti sritis, kur galima atsargiai atskleisti savo savybes ir nebendraujant. Taip palengva numaldomas priešiškumas ir ịsitraukiama ị grupès gyvenimą.

Kita priežastis, kodèl jam patiko eiti ị darbą, buvo pati darbo prasmè: „Nors dabartinis katorgos darbas ir nepelningas, ir nuobodus katorgininkui, bet pats jis, kaip darbas, yra protingas: kalinys daro plytas, kasa žemę, stato namus, tinkuoja; tas darbas turi prasmę ir tikslą" (Dostojevskis, 2006, p. 31). Darbas kartais taip sudomina, kad kalinys stengiasi ji kuo geriau ir greičiau atlikti. Nes motyvuoja pats darbas (gaminti tai, ko reikia). Kalinio darbas nenueina veltui, jo darbo rezultatas tampa apčiuopiamu naudingu produktu. Kitiems naudingas jaučiasi ir pats žmogus, buvimas kalëjime darbo dèka ịgyja 
prasmę. Čia leidžiamas laikas nešvaistomas tuščiai dykinèjant tarp kazarmos sienų. Prasmingas darbas reikalingas ne tik kaliniams, bet ir visuomenei: jų gaminama produkcija naudojosi miesto bendruomenè. Taigi nuteistieji nebėra visuomenès užribyje.

Knygos veikejjo darbo vieta - dirbtuvès, kur jis sukdavo tekèlą. Arba buvo siunčiamas už kalejjimo ribų: statybose padavinèdavo plytas arba degindavo alebastrą. Nors darbai buvo fiziniai, ,man tiko tai, kad nuo darbo manyje, matyt, augo jègos. (...) Fizinè jèga katorgoj reikalinga ne mažiau, kaip ir moralinè, atlaikyti visiems materialiniams to prakeikto gyvenimo sunkumams“, - aiškino Goriančikovas (Dostojevskis, 2006, p. 293). Galimybė dirbant fiziškai sutvirtėti tampa trečiuoju darbo pamėgimo motyvu. Tokius kalinio darbus teko dirbti ir F. Dostojevskiui - daug jègų skyre darbui, kaip sveikatos gerinimo priemonei: „Jis jautè - pamažu stiprejja, ir tai teikè vilčių - gal katorgoje bent pasveiks!“ (Inis, 1999, p. 88). Galimai rašytojas tikejjosi sunkiai dirbdamas pasveikti nuo jị varginusios epilepsijos. Materialūs kalejjimo sunkumai, apie kuriuos kalba Aleksandras Petrovičius, yra gero maisto ir vandens higienai stoka, buities daiktų trūkumas, nepageidaujamų vabzdžių buvimas kazarmose, šaltis arba tvankuma. Fizinis tvirtumas padeda lengviau ištverti šiuos nepatogumus.

Ketvirtoji priežastis, kodẻl norėjo eiti ị darbą, siekis per fizinę veiklą išlieti užgniaužtas laisvès ilgesio emocijas. Užvaldžius tokiai būsenai kalinys staiga su užsidegimu ,pradeda dirbti - dirbti iš visų jègų, lyg trokšdamas darbo sunkumu užgniaužti savyje kažką tokio, kas ji patị spaudžia, myga iš vidaus“ (Dostojevskis, 2006, p. 286). Nuteistasis manè, kad darbas padès jam valdyti emocijas, ịveikti tai, kas slegia. Deja, tai trumpalaiké priemonè, nes esant nelaisvejje laisvės ilgesys visada lieka kartu su žmogumi. Jo neįmanoma užgniaužti. O neleidus prasiveržti kylančioms emocijoms dèl prarastos laisvès gali prasidèti depresija ar pasireikšti agresyvus nekontroliuojamas elgesys. İdomu, kad kalinys pasirenka ne kalbèti apie jausmus, o juos išveikti, t. y dirbti.

Žiemomis Aleksandrui Petrovičiui ir kitiems kaliniams patikdavo kasti sniegą, nes procesas susijęs su linksmybèmis: „Visi nusismagindavo; pasigirsdavo kvatojimų, šūksnių, sąmojų. Pradèdavo svaidytis sniego gniūžtėmis“ (Ten pat, p. 131). Patiriamas vaikiškas nerūpestingumas dirbant yra penkta- 
sis stimulas noriai imtis užduoties. Tiesa, dèl kai kurių kalinių „rimtumo“ ir skirtingų grupių nesutarimų linksmybès neretai baigdavosi plūdimu. Vis dèlto sniego kasimas leidžia užsimiršti, kas esi ir kur esi. Šis potyris žmogų grąžina ị laiką iki kalejjimo ar vaikystès metus. Analizuodamas žmogaus būdą psichologas Alfredas Adleris aprašo gera nuotaika pasižyminčių žmonių, kurie pabrèžtinai džiaugsmingai išgyvena džiugias gyvenimo akimirkas, tipus. Vienas tokių tipų - vaikiškai džiaugsmingi asmenys: „Jų vaikiškumas - tikra širdies atgaiva: jie nevengia uždavinių, imasi jų ir atlieka kažkaip žaismingai ir meniškai“ (Adler, 2003, p. 200). Tokio tipo žmonių kalèjime buvo ir tarp sniego kasèjų, jie savo linksmumu užkrètè ir daugelị kitų smagiai atlikti paskirtą užduotį.

\section{Išvados}

Analizuotame romane kaliniai buvo dviejų tipų - agresyvesni ir ramesni. Pastarujų paveiksluose atsiskleidžia psichologiniai dalykai, padèję ištverti ịkalinimo laiką. Priežastys, lèmusios gerą ar prastą kalinių jauseną ir prisitaikymą, buvo santykis su sąžine, gyvenimo sąlygų laisvèje ir kalèjime skirtumai, gebejjimas pritapti, religingumas. F. Dostojevskis pabrěžia, kad žmogaus sąžinè gali kelti dviprasmiškus jausmus - gailestị arba abejingumą dèl padarytos kaltės. Negalejjimas išgyventi sudètingoje psichologinejje aplinkoje ar patiriant fizinius nepriteklius skatina žmogų nusikalsti, taip ieškant lengvesnio gyvenimo net ir kalejjime. Tikejjimas kaliniams leido išsaugoti viltị, kad ištvers jiems skirtą laiką nelaisveje.

Būtinujų žmogaus poreikių tenkinimo, remiantis A. Maslow'o poreikių hierarchijos piramide, analizė atskleidè, kad žmogui svarbu surasti būdą, net menkiausią (galimai simbolinị, palyginti su galimybėmis laisveje), juos patenkinti, siekiant užsitikrinti savo psichinę gerovę. Pasitenkinimą suteikdavo geresnio, nei duodamas kalèjime, maisto pirkimas. Saugumo poreikị užpildè amatai, leisdavę užsidirbti pinigų, kurie teikẻ galios spręsti, kaip su jais elgtis, pojūtį. Tai ir yra laisvès išraiška. Draugystè su kitu kaliniu patenkino meilès poreikị. Užmegzti tarpusavio ryšiai teikè savęs papildymo, artumo, pagarbos, džiaugsmo emocijų, padejjo įveikti slogią kalëjimo nuo- 
taiką. Itvertinimo poreikị tenkino pasitikejjimas kaliniu kaip žmogumi, kuris nepadarys nieko bloga. Nors tai pasitaikydavo retai (kalejjimo vyresniajam lankant kalinius be sargybinių palydos, be jų einant į cerkvę), skatino abipusę pagarbą. Savęs aktualizavimo poreikị tenkino teatrinė veikla, patenkintas kūrybiškumo poreikis padèjo bent trumpam pamiršti kalëjimo erdvę. Atliekamos individualios funkcijos atskleidžia geriausius asmens gebejjimus, be to, susitelkiama siekiant bendro tikslo, kuris moko bendradarbiauti, suvoki kito žmogaus reikalingumą.

Kalinių laisvès sampratos suvokimas atskleidè, kad ji idealizuojama ir bus vertingesnè išèjus ị laisvę, nei turètoji iki bausmès. Laisvès samprata erdvės požiūriu igavo neribotumo potyrị: „,siaura - platu“, „sava - svetima“. Kalèjimas suvokiamas kaip siaura erdvè, o vieta, kurioje dirbama, kaip plati dèl galimos minčių laisvės ir kalëjimo prižiūrètojų nevaržymo. Kalëjimas suvokiamas kaip svetima vieta, kurioje esama tik laikinai. Laikas nuteistiesiems tarsi nebeegzistuoja, jis tampa reikšmingas tik išejus ị laisvę. Išèjime iš kalèjimo ižvelgiama paralelè su Jèzaus prisikèlimu, suteikianti palaimos emocijų.

Galiausiai privalomas darbas kalèjime pasitarnavo kaip prisitaikymo, fizinio sustiprejimo, užgniaužtų laisvès ilgesio emocijų išliejimo ir pasilinksminimo priemonè. F. Dostojevskis romane darbą išryškino teigiamai dèl pačios darbo prasmès: kaliniai nesijaučia tokie nuasmeninti, kai jų darbo vaisiais naudojosi miesto bendruomenè. Užgniaužtos laisvès ilgesio emocijos sunkiai fiziškai dirbant asmens pasąmonèje nebesikaupia.

\section{Literatūra}

Adler, A. (2003). Žmogaus pažinimas. Vilnius: Vaga.

Almonaitienè, J. (1997). Motyvacija kaip psichologinis kūrybiškumo veiksnys. Psichologija, Nr. 16, p. 65-84. Prieiga internete: https://www.zurnalai.vu.lt/psichologija/article/view/9030/6775 [žiūrèta 2020-12-30].

Bachtin, M. (1996). Dostojevskio poetikos problemos. Vilnius: Baltos lankos.

Bagby, L. (2016). First Words on Dostoevsky's Introductions. Bostos: Academic Sudies Press. Prieiga internete: http://web.b.ebscohost.com/ehost/ebookviewer/ ebook/ZTAwMHh3d19fMTIwMjkzN19fQU41?nobk=y\&sid=14cd92b6-239f4ace-8ddf-f83c8e7c9e32@sessionmgr101\&vid=11\&format=EB\&rid=17 [žiūrèta 2021-02-26] 
Būgaitè, E. (2005). Viltis - laisvès ženklas: hermeneutinès fenomenologijos įnašas. Soter, Nr. 15 (43), p. 191-201. Prieiga internete: https://www.vdu.lt/cris/bitstream/20.500.12259/34220/1/ISSN2335-8785_2005_N_15_43.PG.191-201.pdf [žiūrèta 2021-01-02].

Clear, T. R., et al. (2000). The Value of Religion in Prison: An Inmate Perspective. Journal of Contemporary Criminal Justice, Vol. 16, No. 1, p. 53-74. Prieiga internete: https:/www.researchgate.net/profile/Bruce-Stout/publication/249713505_The_Value_of_Religion_in_PrisonAn_Inmate_Perspective/ links/5750890408aef67d0d89dedb/The-Value-of-Religion-in-PrisonAn-InmatePerspective.pdf [Žiūrèta 2021-02-24].

Červinskienè, E. (2004). Dostojevskis. Vilnius: Margi raštai.

Dostojevskis, F. (2006). Užrašai iš mirusiuju namų. Vilnius: Margi raštai.

Foucault, M. (1998). Disciplinuoti ir bausti: kalejimo gimimas. Vilnius: Baltos lankos.

Fromm, E. (2014). Meilès menas. Kaunas: Verba vera.

Inis, L. (1999). Dostojevskis: biografinè apybraiža. Kaunas: Dajalita.

Young, S. J. (2013). Knowing Russia's Convicts: The Other in Narratives of Imprisonment and Exile of the Late Imperial Era. Europe-Asia Studies. Vol. 65, No. 9, p. 1700-1715. Prieiga internete: http:/ezproxy.biblioteka.ku.lt:3671/ ehost/pdfviewer/pdfviewer?vid=18\&sid=14cd92b6-239f-4ace-8ddff83c8e7c9e32\%40sessionmgr101 [žiūrèta 2021-02-26].

Jacikevičius, A. (1995). Žmonių grupių (socialinè) psichologija. Vilnius: Žodynas.

Kataliku Bažnyčios Katekizmas. (2015). Vilnius: Katalikų pasaulio leidiniai. Prieiga internete: https://katekizmas.lt [Žiūrèta 2020-12-28].

Malkevičiūtè, A. (2003). Tautinio pasaulèvaizdžio atspindžiai XIX a. rusų mąstytojų F. Dostojevskio, V. Solovjovo, S. Bulgakovo žmogaus istorinès būties sampratoje. Logos, Nr. 35, p. 131-139. Prieiga internete: http://www.litlogos.eu/Archive/ logos35.pdf [žiūrèta 2020-12-30].

Malkevičiūtė, A. (2004A). Tautinio pasaulèvaizdžio atspindžiai XIX a. rusų mąstytojų F. Dostojevskio, V. Solovjovo, S. Bulgakovo žmogaus istorinės būties sampratoje. Logos, Nr. 36, p. 71-77. Prieiga internete: http://www.litlogos.eu/Archive/ logos36.pdf [žiūrèta 2020-12-30].

Malkevičiūtè, A. (2004B). Tautinio pasaulėvaizdžio atspindžiai XIX a. rusų mąstytojų F. Dostojevskio, V. Solovjovo, S. Bulgakovo žmogaus istorinès būties sampratoje. Logos, Nr. 37, p. 93-101. Prieiga internete: http://www.litlogos.eu/Archive/ logos37.pdf [žiūrèta 2020-12-30].

Maslow, A. H. (2009). Motyvacija ir asmenybe. Vilnius: Apostrofa.

Maslow, A. H. (2011). Büties psichologija. Vilnius: Vaga.

Myers, D. G. (2008A). Psichologija. Kaunas: Poligrafija in informatika.

Myers, D. G. (2008B). Socialine psichologija. Kaunas: Poligrafija ir informatika. 
Morson, G. S. (2021). Fyodor Dostoevsky: Philosopher of Freedom. The New Criterion, Vol. 39, No. 5, p. 4-9. Prieiga internete: http://ezproxy.biblioteka. ku.lt:3671/ehost/pdfviewer/pdfviewer?vid=7\&sid=14cd92b6-239f-4ace-8ddff83c8e7c9e32\%40sessionmgr101 [žiūrèta 2021-02-26].

Paškus, A. (1995). Žmogaus meilès. Vilnius: Katalikų pasaulis.

Pranciškus. (2016-11-09). Bendrosios audiencijos katecheze. Apie gailestinguma. 35. Lankyti ligonius ir kalinius. Prieiga internete: https://eis.katalikai.lt/vb/popieziai/ pranciskus/audiencijos/2016-11-09 [žiūrèta 2020-12-28].

Šventasis Raštas: Senasis ir Naujasis Testamentai. (2009). Vilnius: Katalikų pasaulio leidiniai.

Visuotinis Vatikano II Susirinkimas. (1965). Pastoracine konstitucija apie Bažnyčia šiuolaikiniame pasaulyje „, Gaudium et spes “. Prieiga internete: https://eis.katalikai.lt/vb/ susirinkimai/vatikano_ii/konstitucijos/gaudium-et-spes [Žiūrèta 2021-02-24].

\section{PSYCHOLOGICAL MEASURES TO SUPPORT HUMAN EXIST- ENCE IN PRISON}

\section{Arvydas Ramonas, Irena Jonikaitė}

Summary

The novel Notes from the House of the Dead by Fyodor Mikhailovich Dostoevsky (1821-1881), a classic of Russian literature, depicts the life of a prisoner experienced by the author himself. He suffered this punishment for his involvement in unauthorized revolutionary activities led by the public figure Mikhail Petrashevsky (1821-1866). The so-called Petrashevsky Society brought together intellectuals and discussed the ideas of state reform and abolition of slavery. However, the community ceased to exist in 1849 imposing a punishment on its members.

In novel F. Dostoevsky allowed some of the characters to remain psychologically resilient despite the environment around them. This was facilitated by the means of satisfying basic human needs, symbolizing freedom, and working as forgetting. Most of the characters are not given names, the character traits are presented as if to suit every prisoner. For example, the desire 
to meet needs was common to all prisoners, not to one specifically. In addition, calmer prisoners were more likely not to give in to dehumanization. The author states in the minds of the main character that just as there are good and bad people in freedom, so there are personalities on both sides in prison. In prison, it is hoped to find some humanity - good between evil.

There were two types of prisoners in the Notes from the House of the Deadmore aggressive and calmer. It was the paintings of the latter that reflected the psychological measures that helped to survive the time of imprisonment. It is a return to morality, seeking answers to the questions of what is good and what is not. In a depressing environment, even the slightest attempt to survive the darkness is noticeable. F. Dostoevsky depicts the picture of a prisoner revealing both sides of it - inhuman degeneration and human potential.

The reasons for the good or bad feeling and adaptation of the prisoners were the relationship to conscience, differences in living conditions in prison and prison, the ability to adapt, and religiosity. F. Dostoevsky raises the idea that prisoners do not feel and understand the meaning of punishment differently due to the conscience. For some, it has become helpful in showing the pain of the damage done and causing a sense of regret. The desire for an easier life becomes a pretext to behave criminally when one no longer tolerates living physically and psychologically in the existing environment of freedom and disregards the norms of ethical behavior. Religious prisoners felt stronger spiritually, without losing their last hope of enduring their allotted time in captivity, portraits of their personalities presented in a brighter, more optimistic way. The non-religious were gloomier, more closed, more trafficked, prone to breaking the prison order, seeing no meaning in life.

An analysis of the satisfaction of essential human needs according to Abraham Maslow's hierarchy of needs revealed that it is necessary for a person to find even the slightest (perhaps seeming only as a symbol in comparison with the possibilities in freedom) ways to satisfy them for their own mental wellbeing. Buying better food than given in prison made me feel the pleasure of satisfaction. The need for security was met by craft activities that made money. Money gave a sense of the right to decide how to deal with it. And it is also an expression of freedom. Friendship with another prisoner met the needs of 
love. The connections made provided emotions of self-replenishment, closeness, respect, and joy, as well as helping to distance oneself from the depressing mood of the prison. The needs for assessment were reflected in the confidence of the prisoner as a person who would do nothing wrong. Although this happens on rare occasions (when a prison elder visits prisoners unaccompanied by guards and goes to church), it promotes mutual respect for humanity. Theatrical activities allow you to express your creativity by meeting the needs of selfactualization and briefly forget about the prison space. The individual functions performed reflect the best abilities of the person. It also unites for a common goal that teaches to cooperate, to see the need of another person.

The convicts felt freedom through the concepts of time (past, future, stagnant time), ritual calculation and space. For F. Dostoevsky himself, freedom was the driving force of both his life and his work. The perception of the concept of freedom by prisoners has revealed that it is idealized and will be more valuable when released than in pre-trial detention. The exit from prison sees a parallel to the resurrection of Jesus, providing emotions of bliss. It should be noted that the convict does not recognize the flow of time and the present of the prison, which is unpleasant for him. The prisoner psychologically displaces the perception of the present time, and the time spent in prison is not counted in life. The concept of freedom in relation to space has acquired the experience of infinite fullness. Space took two forms - "narrow-wide" and "self-alien". The contrast between "narrow-wide" is visible in the premises of the prison and the factory where he worked. The opposition of the "own-foreign" space is noticeable in the perception of the reality of life. The comparison that there is an allusion in the prison as if there is an allusion to the moment of short-livedness - the stay is short, after all, you always return home where you are good.

Finally, compulsory prison work served as a means of adapting, strengthening physically, venting the suppressed emotions of longing for freedom, and having childish fun. In the novel, F. Dostoevsky highlighted the work positively because of the very meaning of the work. Work that makes sense becomes necessary not only for prisoners but also for society. Their products were used by the urban community. As a result, the convicts themselves are no longer on the fringes of society. Prisoners were also encouraged to work by the desire to vent their suppressed emotions of longing for freedom through physical activity. 